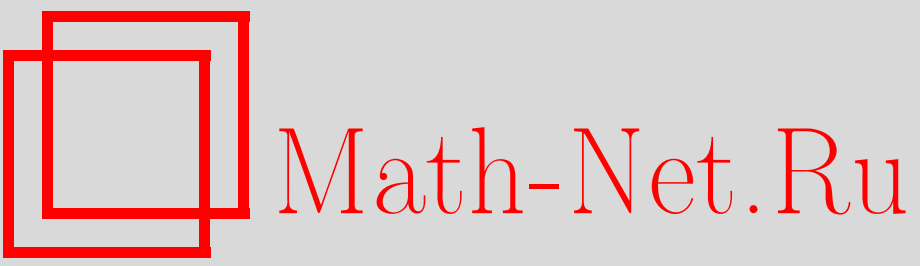

А. М. Вершик, В. А. Залгаллер, С. С. Кутателадзе, В. Л. Макаров, Ю. Г. Решетняк, И. В. Романовский, Геннадий Шлемович Рубинштейн (некролог), $У M H$, 2005, том 60, выпуск 2, 145-146

DOI: https://doi.org/10.4213/rm1409

Использование Общероссийского математического портала Math-Net.Ru подразумевает, что вы прочитали и согласны с пользовательским соглашением

http: //www.mathnet.ru/rus/agreement

Параметры загрузки:

IP: 52.23 .180 .231

26 апреля 2023 г., $14: 16: 29$ 


\section{ГЕННАДИЙ ШЛЕМОВИЧ РУБИНШТЕЙН}

2 мая 2004 г. на 82-м году жизни скончался доктор физико-математических наук, профессор Геннадий Шлемович Рубинштейн, ученик и соратник Л.В. Канторовича в деле развития математико-экономических методов и близких вопросов функционального анализа.

Г. Ш. Рубинштейн родился 26 апреля 1923 г. в Одессе. После окончания средней школы в 1940 г. он поступил на физико-математический факультет Одесского госуниверситета, но учебу прервала война. Рубинштейн прошел всю войну от обороны Днепропетровска до взятия Берлина вначале рядовым, а затем, после окончания Куйбьшевского военного училища, командиром подразделений связи действующей армии. Его боевые заслуги были отмечены двумя орденами Красной Звезды и медалями.

После демобилизации в 1946 г. Геннадий Шлемович возобновил учебу в Одесском госуниверситете. С четвертого курса он перевелся в Ленинградский госунивер-

ситет, которьй и закончил в 1949 г. Уже в студенческие годы Рубинштейн активно включился в научную работу. Встреча с Канторовичем во многом определила дальнейший путь молодого ученого и стала началом их многолетнего сотрудничества. Его дипломная работа "О разделении вьпуклых множеств" представляет обстоятельное исследование по теории вьпуклых множеств, в котором был разработан геометрический подход к установлению теорем отделимости для выпуклых множеств в линейных пространствах общего вида и приведен рядинтересных приложений этих теорем.

В 1949-1952 гг. Г. Ш. Рубинштейн работал старшим инженером-технологом Кировского завода, с 1952 по 1956 гг. - учителем математики в одной из ленинградских школ. Одновременно он вел преподавательскую работу в Текстильном институте и Военно-морской академии им. А.Н. Крылова. В 1956 г. после зашиты кандидатской диссертации Г.Ш. Рубинштейн перешел на основную работу в Военно-морскую академию, совмещая ее с преподаванием в Ленинградском госуниверситете, где он прочел первый курс математического программирования на матмехе ЛГУ и на знаменитом "шестом курсе" экономического факультета. С 1958 г. он стал (по совместительству) научным сотрудником Лаборатории по применению математических методов в экономике Сибирского отделения Академии наук. В 1962 г. Г. Ш. Рубинштейн переехал в Новосибирский академгородок, где вплоть до своей кончины состоял в штате Института математики им. С. Л. Соболева. В 1965 г. он защитил докторскую диссертацию. Долгие годы Г. Ш. Рубинштейн заведовал отделом выпуклого анализа и теории экстремальных задач и работал профессором Новосибирского госуниверситета.

Г.Ш. Рубинштейн - автор около 100 научных работ, посвященных разнообразным задачам анализа и его приложений. Основные его исследования сосредоточены в следующих трех направлениях: теория выпуклых множеств и выпуклых функций, теория двойственности для экстре- 
мальных задач, численные методы математического программирования и их применения в планово-экономических задачах. Все три цикла тесно связаны тематически и неразделимы во времени. Характерной особенностью творчества Г.Ш. Рубинштейна является взаимопроникновение идей и методов различных областей математики.

Разработанньй Г. Ш. Рубинштейном элементарно-геометрический подход к построению теории выпуклых множеств, опирающийся на проведенное им исследование граневых строений, позволил получить практически окончательные формы теорем об отделимости выпуклых множеств в общих линейных пространствах. Более того, эти теоремы устанавливаются в так называемых осевых пространствах, включающих помимо линейных пространства Лобачевского и некоторые другие. Развитый при этом аппарат позволил одновременно решить некоторые задачи, относяшиеся к основаниям геометрии.

Г.Ш. Рубинштейн предложил и детально разработал один из наиболее общих подходов к построению двойственных экстремальных задач, в котором существенную роль играют теоремы отделимости выпуклых множеств. При этом наряду с классическими теоремами систематически был использован ряд более тонких теорем отделимости. Первым вариантом в построении указанного подхода стало исследование геометрической задачи о крайней точке пересечения оси с выпукльм множеством. С помощью такой частной схемы двойственности Г. Ш. Рубинштейн изучил различные классы задач линейного и выпуклого программирования, теории игр и наилучшего приближения.

Особо следует отметить серию совместных работ Л. В. Канторовича и Г.Ш. Рубинштейна, связанных с проблемой Монжа. Развитый при решении этих задач аппарат прочно вошел в математический тезаурус. Исследованию функционального пространства Канторовича-Рубинштейна посвящено значительное число теоретических и прикладных работ. В дальнейшем Г.Ш. Рубинштейн на основе разработанной им общей теории получил ряд новых важных результатов по конкретным конечномерным и бесконечномерным экстремальным задачам. Им были получены изящные результаты о преобразовании квазивыпуклых функций в выпуклые, представляюшие собой принципиальное решение проблемы, поставленной Фенхелем еще в 1953 г. В области численных методов математического программирования основные результаты Г. Ш. Рубинштейна связаны, в первую очередь, с созданием специальных алгоритмов для решения задач большого объема. Он предложил ряд эфффективных идей использования специальной структуры матрицы, позволивших создать экономные вычислительное схемы для задач линейного программирования блочной структуры. Огромная заслуга принадлежит Г.Ш. Рубинштейну в пропагандировании методов линейного программирования, особенно в первые годы становления этого направления в нашей стране. Под руководством Г.Ш. Рубинштейна в то время был осуществлен ряд работ по внедрению методов линейного программирования в хозяйственную практику, в частности, в планировании заказа и раскроя промышленных материалов на Кировском заводе, Московском заводе малолитражных автомобилей и др.

Наряду с научной и научно-производственной деятельностью большое внимание Геннадий Шлемович уделял подготовке кадров. Ему принадлежит заслуга постановки одного из первых в стране университетских курсов математического программирования. Итогом многолетней лекторской работы Г.Ш. Рубинштейна стал его учебник "Конечномерные модели оптимизации", послуживший основой книги "Математическое программирование", написанной совместно с Э. А. Мухачевой. Лекционные курсы, семинары, руководимые Г. Ш. Рубинштейном, всегда привлекали молодежь. Работе с молодыми учеными Г.Ш. Рубинштейн уделял огромное внимание, не жалея ни времени, ни сил.

Все, кто знал замечательного ученого и человека, Геннадия Шлемовича Рубинштейна, сохранят о нем добрую память.

A. М. Вериик, В. А. Залгаллер, С. С. Кутателадзе, В. Л. Макаров, Ю.Г. Решетняк, И. В. Романовский 